\title{
Gender empowerment approaches: interventions through Qanun number 6 of 2009 in Aceh, Indonesia
}

\author{
Adrianto Shifa Al Aro, Aini Saniyah, Fahima Ulumia, Nur Azkiyatuz Zahro, Nur Ayumi, Milta Charennina, \\ Wikan Amarudin Fahmi, dan Ratih Fitria Putri*
}

Department of Environmental Geography, Faculty of Geography, Universitas Gadjah Mada

\begin{abstract}
Aceh is a province in Indonesia that makes Islamic sharia as one of the bases in policy determination, one of which is policies related to gender empowerment. It is interesting to be studied about the condition of gender empowerment in Aceh, especially after the ratification of Qanun Aceh No. 6 of 2009 on Women Empowerment and Protection. The study used descriptive qualitative analysis of secondary data obtained from BPS Aceh Province. The results showed that the implementation of Qanun No. 26 of 2009 related to the empowerment and protection of women is still not done to the maximum, either explicitly or implicitly. This is evidenced by the condition of Aceh Gender Empowerment Index which has a volatile trend from 2010 - 2019 with an index ranging from 52.06 to 67.4 . The trend is strongly influenced by the three components of GEI, namely women's involvement in parliament, women's involvement as professionals, and women's income donations. The involvement of women in parliament still does not meet the minimum figure of $30 \%$. The involvement of women as professionals has a volatile trend. Meanwhile, women's income contributions always increase every year.
\end{abstract}

\section{Introduction}

The term 'gender' comes from the Latin word "genus" meaning birth, family or idea [1]. In the social field, gender includes a role in the social development of society that is not determined by gender. Therefore, every man and woman must have equal rights in social life. However, physical differences make people think that men have a higher level of social life in society, whereas the rights of men and women in social life are actually the same [2].

At the heart of the various definitions and meanings of gender is the thought that men and women are on the same platform in social life. In general, world-class institutions are attuned to the idea that the role of women is often subjugated by social norms. The imbalance causes the gender gap i.e., both men and women lag their peers on key developmental indicators such as education and income. Although many development practitioners still confuse the approach of gender equality with women's empowerment, the gender approach has gained significant place at least at the time of policy formulation.

Women in some developing countries suffer from gender inequality. Countries such as Yemen, Chad, and Pakistan have been ranked at the bottom of the Global Gender Gap Index according to the World Economic Forum. In Indonesia, for example, there are 96\% male literacy, but only $90 \%$ women are literate. A total of $86 \%$ of men participate in the labor market, but only $53 \%$ of women do so. It also occurs in income conditions between men and women. Men on average earn US\$6,903, but women only get US\$2,985. Only one in five legislators, senior officials, and managers are women [3]. The approach of empowering women especially by means of education and extensive training to develop their capacity is essential for other empowerment measures that need to be taken by the government.

Aceh is a province in Indonesia that makes Islamic sharia as one of the basic in policy determination, one of which is the policy that governs the empowerment and protection of women. This policy is published in Qanun Aceh No. 6 of 2009 which is made on the basic of several considerations that refer to the Quran, Al-Hadith, and some state regulations in the form of law and government regulations. One of the provisions written in Qanun Aceh is that the Government of Aceh provides the widest possible access for women to participate in the labor market, economic activities, and public space. This makes the issue of women empowerment in Aceh Province an interesting thing to be raised considering the role of women and Islamic sharia is an inseparable thing [4].

This study aims to find out the condition of gender empowerment in Aceh Province, especially after the publication of Qanun Aceh Number 6 of 2009. This study explains the Gender Empowerment Index (GEI) and

\footnotetext{
${ }^{*}$ Corresponding author: ratihfitria.putri@ugm.ac.id
} 
trends over the last ten years along with its three main components in Aceh Province. GEI's main components include the involvement of women in parliament, donations of women's income, and women as professionals. GEI condition in Aceh Province is described in the form of a graph chart based on the year and administrative area of the district/ city.

\section{Data and Methods}

The research method used is qualitative with a review of previous literature studies. The data and information obtained are analysed using descriptive analysis. The selection of research subjects was conducted using regional case studies at the Aceh Province level.

This study uses the publication data of Aceh Province in figures from 2011 - 2021 collected through secondary data from the Central Statistics Agency of Aceh Province, the publication of the Ministry of Women Empowerment and Child Protection in the 2020 GenderBased Human Development Report, and the legislation of the Ministry of Law and Human Rights. The data used in this study include:

1. The Gender Empowerment Index data and its components include women's involvement in parliament, involvement of women as professionals, and donations of women's income in society.

2. Regulation of the Special Region of Aceh Province in the form of Qanun Aceh Number 6 of 2009 concerning The Empowerment and Protection of Women.

\section{Results and Discussions}

\subsection{Gender empowerment index}

Gender Empowerment Index (GEI) is one of the main indicators in measuring the success of human development in an area. The index is derived from the arithmetic average of three main components, namely the involvement of women in parliament, women as professionals, and the contribution of women's income [5]. Based on this, it can be said that the dynamics of GEI are closely related to the level of female participation in public spaces and economic activities. GEI in each province in Indonesia has a number and trends are quite varied. There are provinces with GEI numbers that are larger than the national GEI, there are also provinces with GEI that are worth less than the national GEI, one of which is the GEI of Aceh Province which is presented in figure 1 .

The picture shows that the Gender Empowerment Index (GEI) of Aceh Province is experiencing a patterned volatile trend. The increase in GEI figures continuously occurred in 2010-2016 and 2017-2018. GEI's figure increased by 14 points during 2010-2016, from 53.4 in 2010 to 67.4 in 2016, while in 2017-2018 there was an increase of 0.32 points. The increase in GEI figures indicates that the role of women in Aceh Province in decision making, economic activity, and employment is increasing, and gender disparity is decreasing. The decrease in GEI figures occurred in the period 2016-2017 and 2018-2019. The decrease in 2016-2017 was 0.1 while in 2018-2019 there was a decrease of 0.29 points. The decrease in GEI figures in Aceh Province indicates that the role of women in decision making, economic activities, and employment is decreasing, and the disparity of gender roles is increasing.

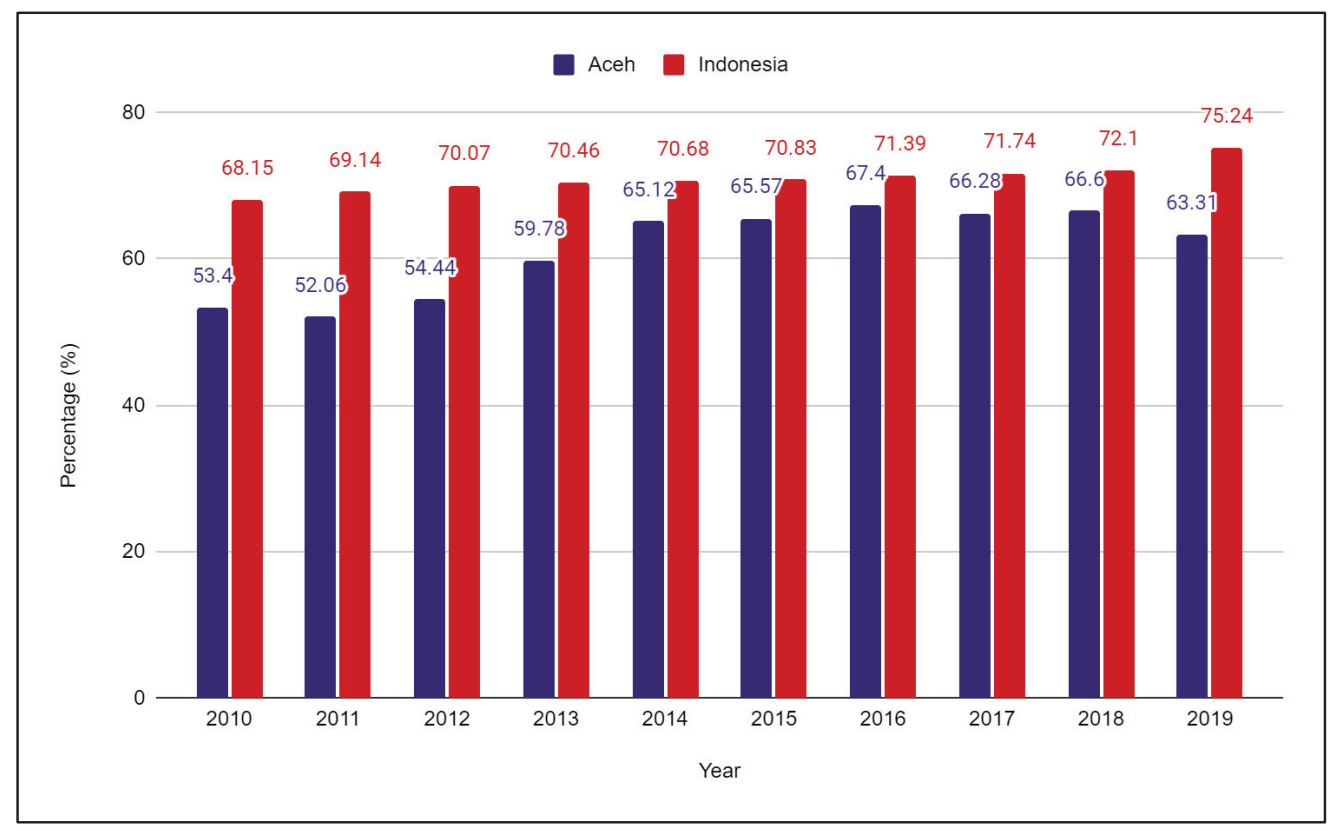

Fig. 1. Gender Empowerment Index (GEI) in Aceh Province and Indonesia 2010-2019 Source: BPS, processed (2021) 


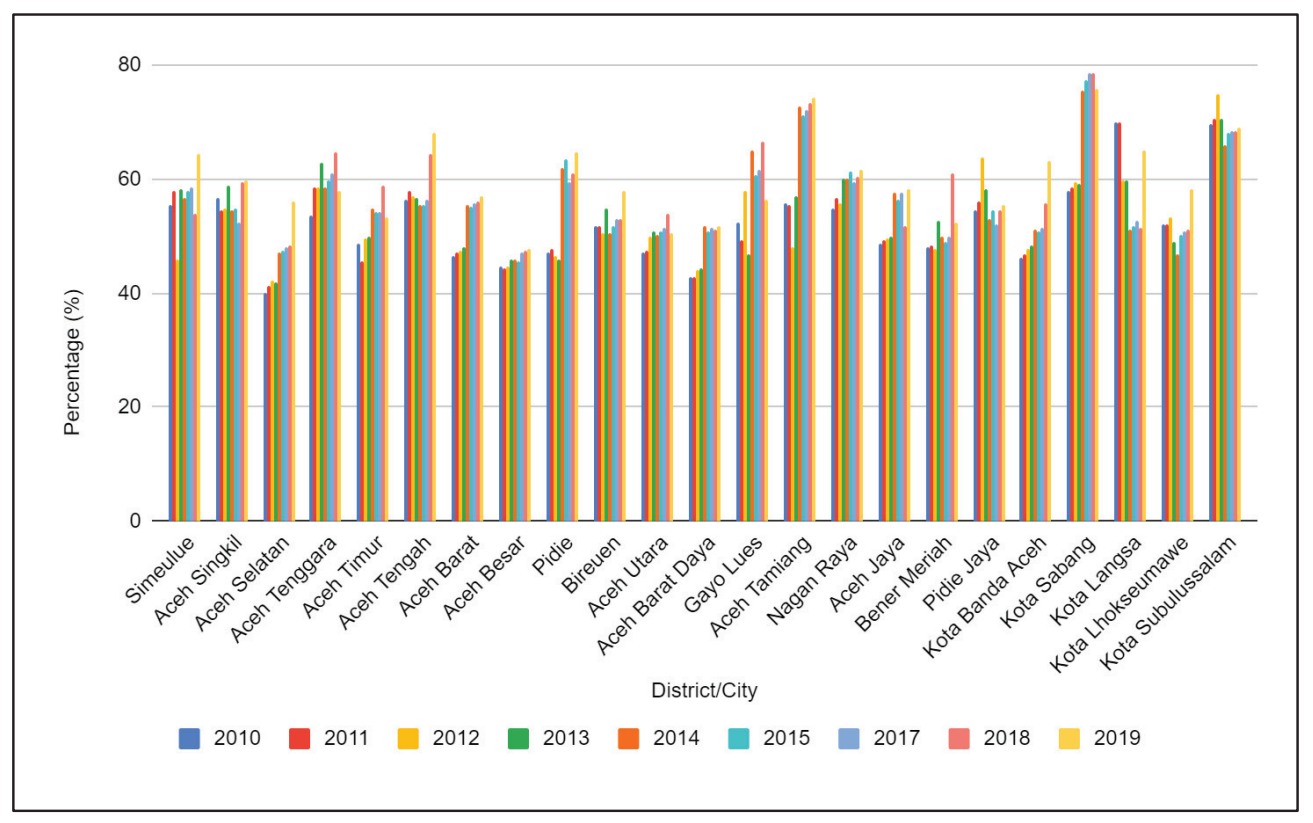

Fig. 2. Gender Empowerment Index (GEI) in Aceh Province by District/City 2010-2019

Source: BPS, processed (2021)

The fluctuating trend of GEI figures in Aceh Province shows that throughout 2010-2019 there was a dynamic level of participation and awareness of women in public spaces and economic activities.

The distribution of Gender Empowerment Index (GEI) in Aceh Province by district and city changed in 2010 and 2019, as shown in figure 2. In 2010, there were two administrative districts that had a number of $60 \leq \mathrm{GEI}<70$, namely Subulussalam and Langsa, while other districts and cities had GEI numbers $<60$. This shows that the level of women's participation in public spaces and economic activities in Subulussalam and Langsa city is quite good / middle class compared to other cities and districts. Other cities and districts with low GEI levels (GEI < 60) in Aceh Province showed that in 2010 , women's awareness of the importance of contributions in public spaces and economic activities was still likely to be low. The distribution of GEI numbers in 2019 shows that the administrative areas that have the number $60 \leq$ GEI $<70$ are Banda Aceh, Subulussalam, Central Aceh Regency, Pidie, Nagan Raya, and Simeulue. Administrative areas with GEI numbers $\geq 70$ are Sabang city and Aceh Tamiang regency, while other districts and cities have GEI numbers $<60$.

Based on the distribution of GEI figures in 2010 and 2019, it is known that Sabang city and Aceh Tamiang district experienced a very significant increase in GEI figures compared to other districts and cities in Aceh Province. Aceh Tamiang district had a GEI number of 55.78 in 2010 and rose to 74.39 in 2019, an increase of 18.61 points over the last nine years. Sabang city has GEI number of 57.92 in 2010 and rose to 76.01 in 2019 , an increase of 18.09 points over the last nine years. The large number of
GEI increases even exceeded the increase in GEI figures of Aceh province and nationally. The rapid increase in GEI numbers in Sabang and Aceh Tamiang districts is influenced by the high involvement of women in parliament compared to other districts/cities. This shows that the level of women's awareness of the importance of contributing to public spaces is increasing along with wide-open opportunities and opportunities for women to participate in political activities and public spaces.

The efforts of the Aceh Provincial Government related to increasing gender empowerment in Aceh Province can be proven by the existence of Qanun Aceh Number 6 of 2009 on Women Empowerment and Protection. Qanun is a type of local legislation that regulates the administration and life of the people in Aceh Province. Qanun Aceh is a regulation that applies throughout Aceh Province, while Qanun only applies in certain districts/cities. Based on the qanun, women's empowerment and protection aim to strengthen women's participation in the development process, improve the quality of life of women to be able to play a balanced role with men in various aspects of life that are relevant, provide assurance to women to be able to fulfill their rights as human beings in all aspects life and provide a sense of security to women in all aspects of life. The Qanun becomes a regulation that clarifies the previous regulation, namely Law Number 11 of 2006 on the Government of Aceh which provides an opportunity for representation.

Unlike GEI in Aceh Province which still tends to be low and has a fluctuating trend, Central Kalimantan Province has the highest GEI value compared to other provinces in Indonesia in recent 
years. The GEI of Central Kalimantan Province in 2010 was 68.62 and has a tendency to increase every year to 83.20 in 2019 [6] which is also the highest GEI value in Indonesia. Not much different from Aceh Province, Central Kalimantan also has a legal foundation that regulates gender empowerment, namely Central Kalimantan Governor Regulation No. 4 of 2014 on Gender Mainstreaming in Regional Development in Central Kalimantan. Although both have regulations governing gender empowerment, the success of GEI Aceh province and central Kalimantan seems to show a considerable gap. Reporting from an article written by [7] from the Office of Women Empowerment, Child Protection, Population Control and Family Planning of Central Kalimantan Province web, the success of GEI in Central Kalimantan Province is due to the strong government's commitment in the implementation of Central Kalimantan Governor Regulation No. 4 of 2014. The government is considered to have a strong commitment in ensuring equal rights between men and women in the economic, political, sociocultural, and legal fields so as to encourage the realization of gender equality and justice in Central Kalimantan Province.

Similar to Aceh Province, another province that still has a low GEI in Indonesia is Papua Province. In 2010 the GEI of Papua Province was only 55.42 but the numbers showed a steady increase every year, until in 2018 the GEI of Papua Province was 68.71 [6]. The development strategy in Papua Province so far has been directed at empowering the community in general and increasing the role of the private sector in community affairs that have not been optimally carried out by local governments. The role of private institutions in absorbing women's employment in Papua Province has been quite high. Although the increase has not been so significant, it can be seen that women's participation is already quite high. Until 2019, women's participation in the private sector reached $42.35 \%$. The legal basis for gender empowerment in Papua can be seen from the role of the government by issuing Law No. 21 of 2000 on Special Autonomy, and is still in the evaluation process. Under the provisions of this special autonomy law, women get improved certainty over their participation in determining local policies through the Papuan People's Council (MRP). In this assembly representing the Papuan people who are segregated into various ethnic groups, women's groups get a quota of one third $(1 / 3)$ of the seats in the MRP. This opens up opportunities for women to be able to erode various gender inequalities caused by social and cultural aspects.

\subsection{Women's Involvement in Parliament}

Parliament in governance in Indonesia is synonymous with legislative institutions. In addition, everything that has something to do with government is to tighten leadership or leadership. Today, the empowerment of women in various dimensions of life gets global attention, including in the field of government, especially for observers of development issues. This is in line with the fact that women are often considered to be discriminated against in terms of taking on strategic roles including in politics.

In a democratic country, the involvement and participation of women and men in public policy drafting positions occupied the same position. This is in line with efforts to produce a decision that impacts the balance of society at all levels, as well as the realization of achieving goals and justice. However, in the implementation in the field, it seems that women are still more objects than subjects. The cause of this persistence of the phenomenon is due to patriarchal thinking that makes women's confidence to take a role in politics very low. According to Law Number 11 of 2006, the representation of women in parliament is at least $30 \%$ [8]. The representation of women in parliament is also very important in public decision making. This will bring different women's perspectives in seeing and solving various public problems, because women will think more holistically and responsive to gender.

Figure 3 shows women's involvement in parliaments in Aceh and Indonesia provinces. Based on the chart, the percentage of women's involvement in parliament in Aceh Province is lower than in Indonesia. The trend of the percentage of women's involvement in parliament in Aceh Province is quite volatile from year to year. The percentage of female involvement in parliament in 2010 was $5.8 \%$ and then decreased in 2011 to $4.35 \%$. That figure then increased to $5.8 \%$ in 2012 . The number of women involved in parliament then increased significantly in the following year, namely in 2013 to 2019 with a percentage ranging from $10.14 \%$ to $16 \%$. The increase in the percentage of women's involvement in the parliament had a positive impact after the enactment of the Qanun on empowerment and protection for women in 2009, especially in article 8 governing women's rights in politics.

Under the article, women are entitled to political positions, both in the executive and legislative environment proportionally. Women are also entitled to conduct various political activities in accordance with the laws and regulations and are entitled to occupy the position of every level of management of political parties and local political parties. In addition, women are also entitled to be nominated as members of the legislature by national political parties as well as local political parties in accordance with their abilities. 


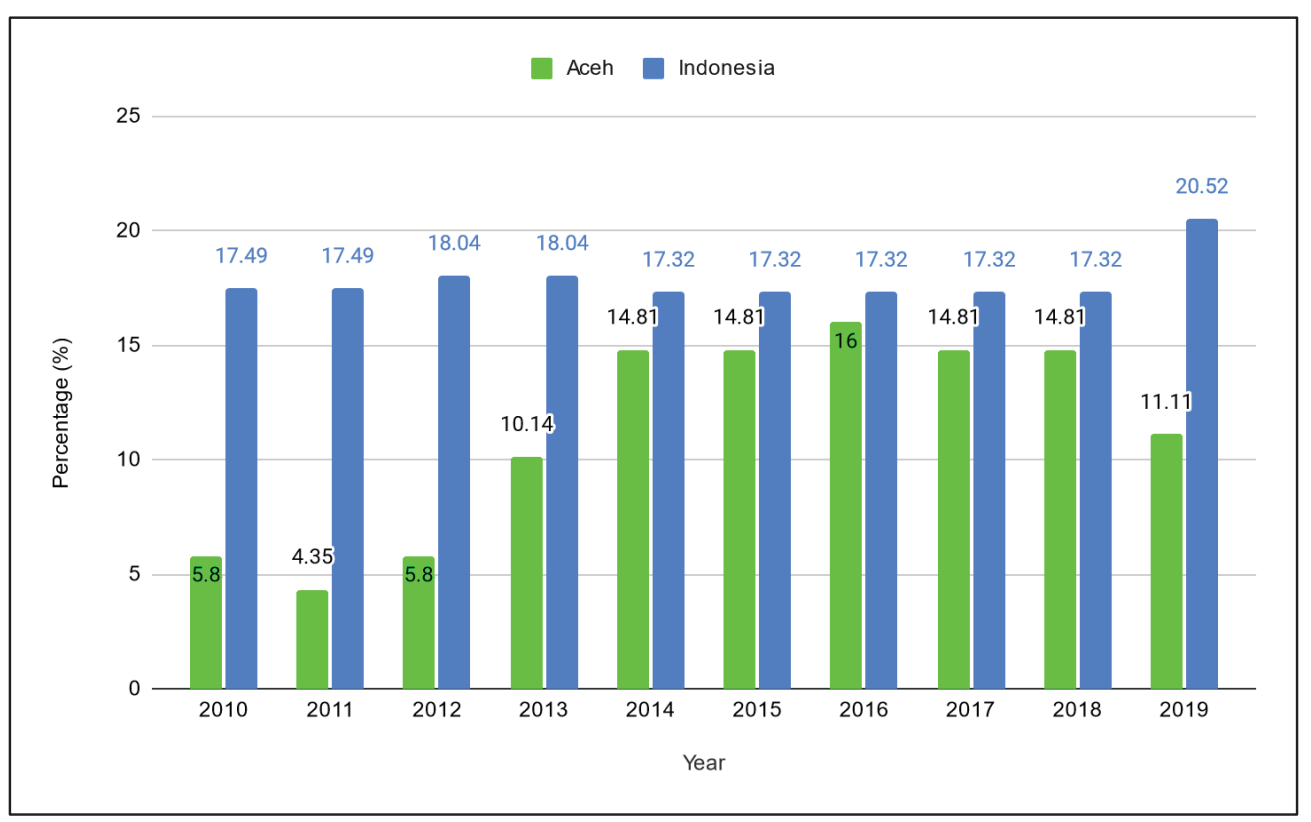

Fig. 3. Women's Involvement in Parliament in Aceh Province and Indonesia 2010-2019 Source: BPS, processed (2021)

The involvement of women in parliament in Aceh Province by district/city is represented in figure 4. Based on the chart, the percentage of female involvement in parliament in each district/city varies greatly. The percentage trend each year is also very varied because there are districts/cities that experience decreases and increases. Aceh Tamiang district has the highest average involvement of women in parliament in Aceh Province at $23.33 \%$ because in $2010-2019$ it had a percentage that is between 13.33 to $36.67 \%$. Sabang city also has a high average of $20 \%$ with the percentage of women's involvement in parliament around $10-30 \%$.

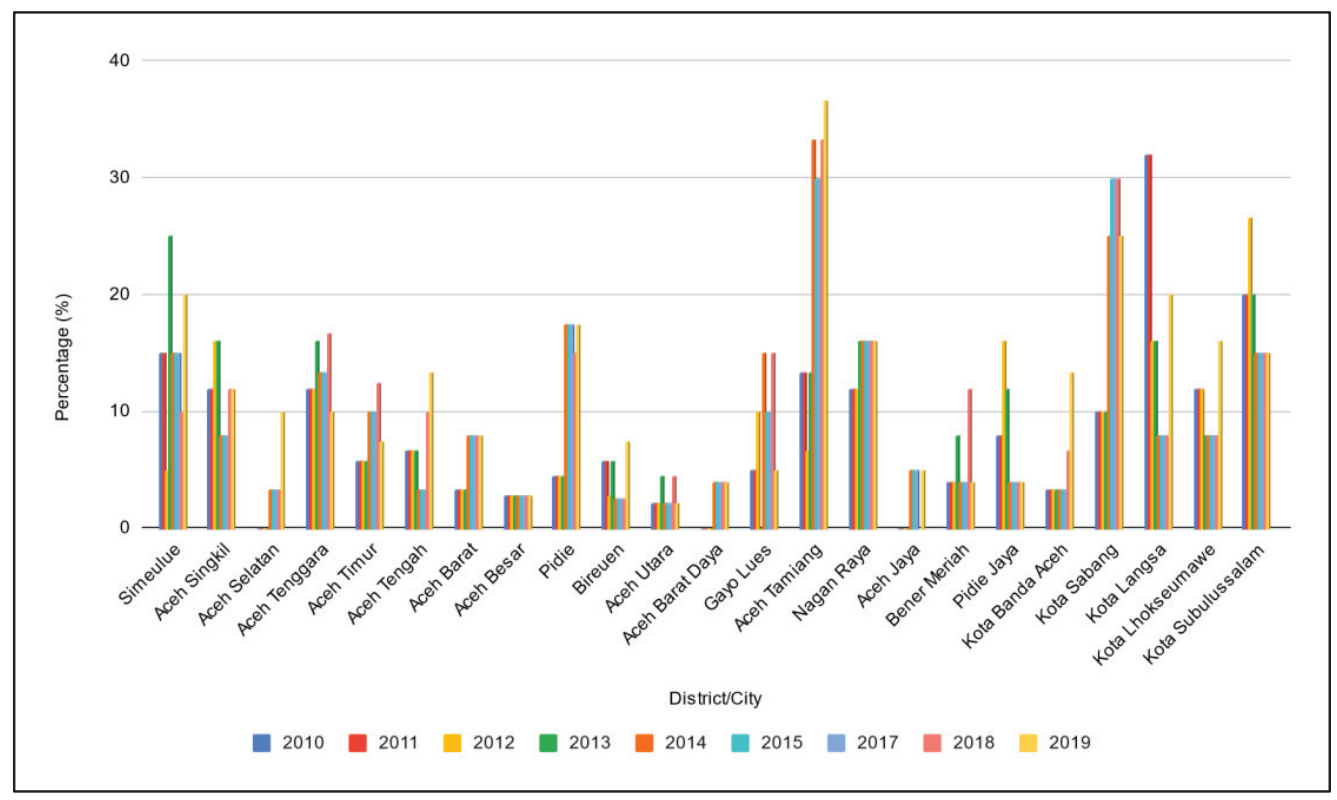

Fig. 4. Women's Involvement in Parliament in Aceh Province by District/City year 2010-2019

Source: BPS, processed (2021) 
Meanwhile, the average percentage of female involvement in other district/city parliaments is around 2.6-17.96\%, In general, the involvement of women in parliament in Aceh Province in 2010 to 2019 has not qualified at least $30 \%$ because the percentage in 2010 to 2019 is only about $4.35 \%$ to $16 \%$. When associated with the existence of Qanun Aceh Number 6 Year 2009, the application of Qanun is not spread evenly in each district/city to create a gap. This can be because in article 4 of Qanun Aceh Number 6 of 2009, women empowerment and protection activities are carried out and coordinated by the Aceh Device Work Institute or District/ City. The condition causes a difference in the implementation of women's empowerment and protection in each district/city and the impact is the percentage of women's involvement in parliament is also different.

Rule related to women's empowerment is also carried out in other countries, one of which is in Kenya. Kenya has an important role in the development of women's empowerment in the world because Kenya was once the site of the Third World Conference of Women in 1985 that was organized by the United Nations in Nairobi. The conference provides a great opportunity for women in Kenya, especially to improve gender equality [9]. Meanwhile, Kenya was also one of the countries that ratified article 9 of the Maputo Protocol on October 6 , 2010. The article discusses women's equality, which has to do with the representation of women in parliament. Meanwhile, there was a change in the constitutional rules in 2010 , namely the two third gender rule. Under the rules, $2 / 3$ of lawmakers cannot have the same gender. This means that there are opportunities for women, one of which is related to the provision of special seats for women. Both have greatly affected the number of representations in Parliament in Kenya which increased from 7.1\% in 2005 to $19.7 \%$ in 2015 [10]. This condition shows that the role of the government is very important in increasing women's empowerment.

\subsection{Women's Income Contribution}

The Gender Empowerment Index (GEI) shows whether women can actively participate in economic and political life. GEI focuses on participation, by measuring gender inequality in the economic, political, and decision-making fields. One of GEI measurement indicators is the female income contribution figure. The income of female workers is still far enough away with male workers or there is still inequality. In Indonesia, women's income contribution is always lower compared to men. Indicators of women's income contribution are influenced by many factors, including education level, work experience, number of family dependents, variable age and working hours [11].
The number of women working in Indonesia as well as in some areas such as Aceh Province will continue to increase every year from 2010 to 2019 as shown in figure 5. The percentage of women's income contribution in Aceh province has increased every year although not very significant, from $31.67 \%$ in 2010 to $34.59 \%$ in 2019 . This is because along with the increasing learning opportunities for women, the success of government programs in the field of family planning, the increasing number of day care centres and the increasingly sophisticated technology to support the dual role of women, as housewives and as workers. The increased desire of women to work not only affects the job market, but also affects the economy and well-being of the woman herself and her family. The increasing income of housewives, the more welfare, nutritional quality, and health of the whole family [12].

The increase in the value of women's income contribution in Aceh Province is still smaller or below the national standard which ranges from $33.5 \%-37.1 \%$. This is due to several things. First, the slow and unaligned growth of the industry population. Aceh province is still improving in developing its regional industry. Currently, there is practically no reliable regional industry as a source of livelihood for Acehnese people. Business movements were hampered after the tsunami that destroyed many potential areas.

Second, women are still considered to have competence under men, so women are often less prioritized as employees. In addition, employment opportunities for the male population are more widely open than those of female residents. Many primary school-age residents ( $7-15$ years old) who do not attend school for financial reasons, choose to work in various informal sectors [13]. The achievement of education for women in Aceh Province is not in line with their achievements in the world of work. Although more and more women get the opportunity to go to school, they have difficulty getting suitable jobs after graduation.

Job openings are few and women choose to relent to men when competing for certain positions. The lack of job openings in Aceh leads to a low availability of female workers in accordance with their areas of expertise, so women's income contributions tend to be lower and there are gaps.

The gender-based wage gap is the real thing that harms women by suppressing their incomes. Efforts to address the wage gap between genders must be made by analysing the economic use of a region first. It is intended to know whether or not there is a case between the use of economic resources for women and men in terms of education and career choices [14]. Furthermore, women who have their own income will have more choices. Women who have a large contribution to the family economy will tend to play a role in decision making in their household. 


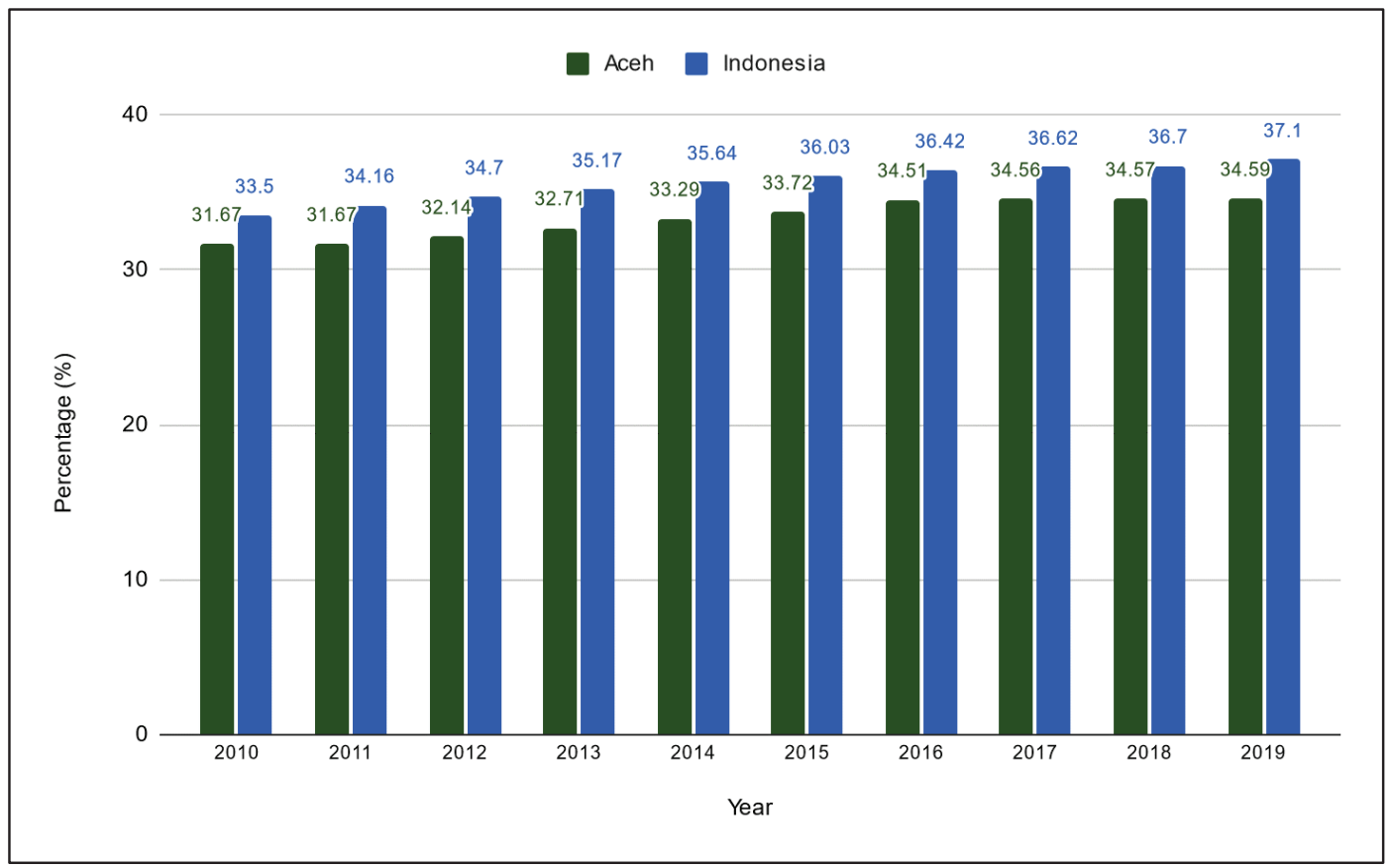

Fig. 5. Women's Income Contribution of Aceh and Indonesia Provinces in 2010-2019

Source: BPS, processed (2021)

The role and participation of women in the world of work, has managed to contribute quite large to the welfare of the family, especially in the field of economics. In Aceh Province, the value of women's income contribution has varying conditions in each district or city and looks volatile every year from 2010 to 2019. Districts that have a high value of women's income contributions, including Central Aceh Regency, Bireuen Regency, Gayo Lues Regency, and Aceh Jaya Regency. The district is largely dominated by rural areas with most of the poor. Based on figure 6 , it can be interpreted that the number of female residents entering the job market is greater than the male population and the number of female residents is indicated more in rural areas.

Rural women are more aware and understand their position in addition to being housewives also have a role to help families in fulfilling the needs of life that tend to do any work [15]. Women in rural areas are mostly involved or working in trade and agriculture, namely as rough laborers of coffee plantations and farm laborers. However, the contribution of women's income in this region plays a big role because in general the income of women families belonging to the poor category can increase and can help increase the overall income of the family.

In contrast to rural areas, in urban areas that have the highest percentage of female income contribution is Subulussalam City. Banda Aceh, which is the urban center and the capital of Aceh Province, has a percentage of women's income contributions that tend to be moderate. This is because the work that many women in Banda Aceh are working in the informal sector due to the level of education and skills(skills) that have not been able to enter the formal market, so the contribution of income generated is relatively small [16]. In addition, most of the conditions in the household in urban areas the largest income contribution is still held by the man/husband who is the head of the household.

When it is associated with Qanun Aceh Number 6 of 2009, there is an article that supports the increase of women's income contribution through empowerment in the economic field, namely article 15. Based on this article, the government of Aceh and districts /cities facilitate women's access to economic resources, employment opportunities, markets, and trade. In addition, the government also provides access to employment, adequate working conditions, and control of economic resources. The Government of Aceh also provides business services, training, and access to markets, information, and technology, especially for lowincome women. However, the implementation of qanun is still not maximized because although there has been an increase in the percentage of income contributions each year, the increase has not been significant. 


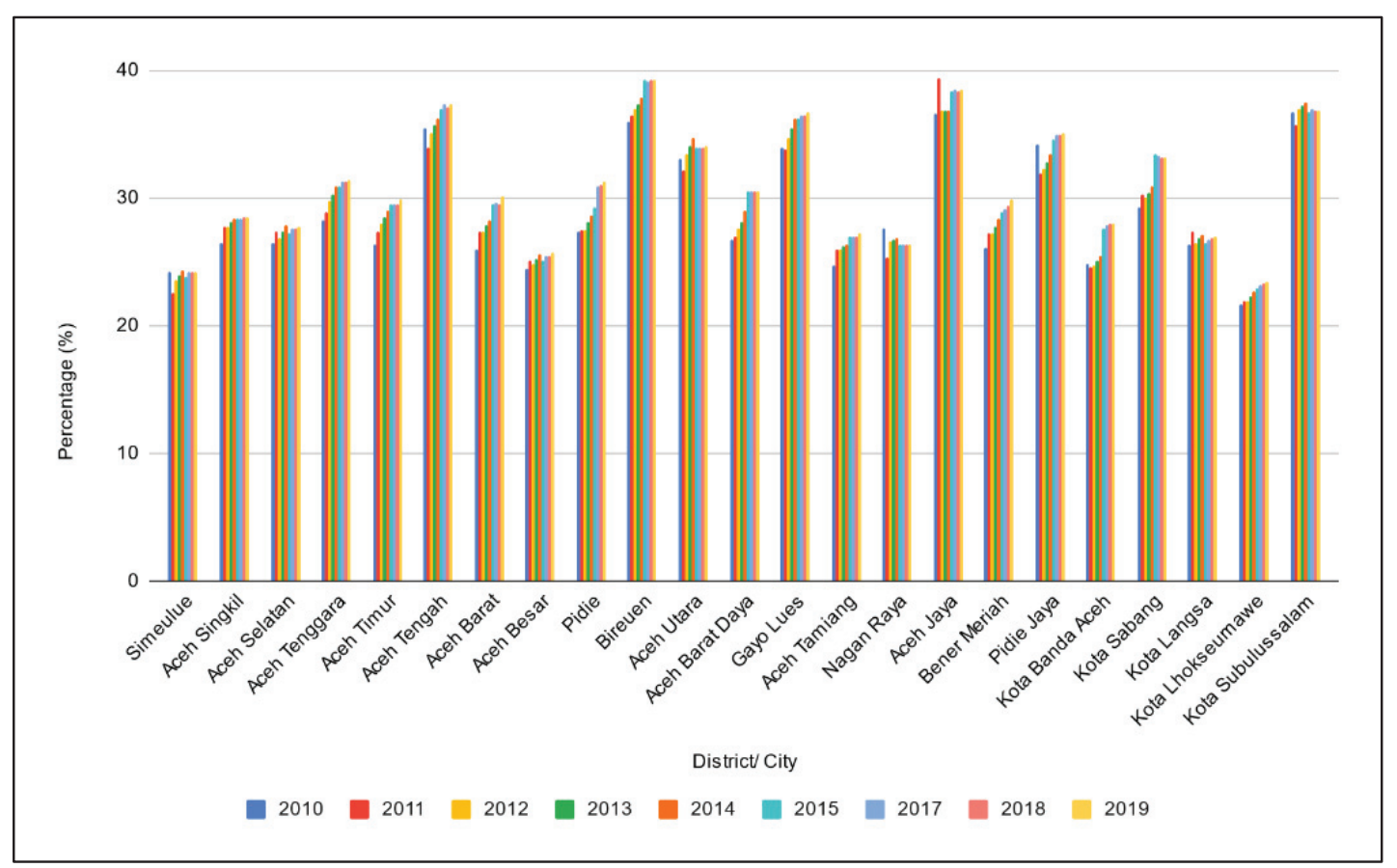

Fig. 6. Aceh Province Women's Income Contribution by District/City 2010-2019 Source: BPS, processed (2021)

\subsection{Involvement of Women as professionals}

The involvement of women as professionals is driven by birth rate, life expectancy, literacy rate, average female school time, urbanization rate and women's contribution to household income [17]. In 2009, Aceh Province implemented a regulation that regulates the involvement of women as professionals in both the formal and informal sectors. The regulation in question is Qanun Aceh Number 6 of 2009 concerning The Empowerment and Protection of Women. The impact of the implementation of the regulation, in Aceh Province in 2010 to 2019 , has a percentage of women's involvement as professionals that always exceeds national trends.

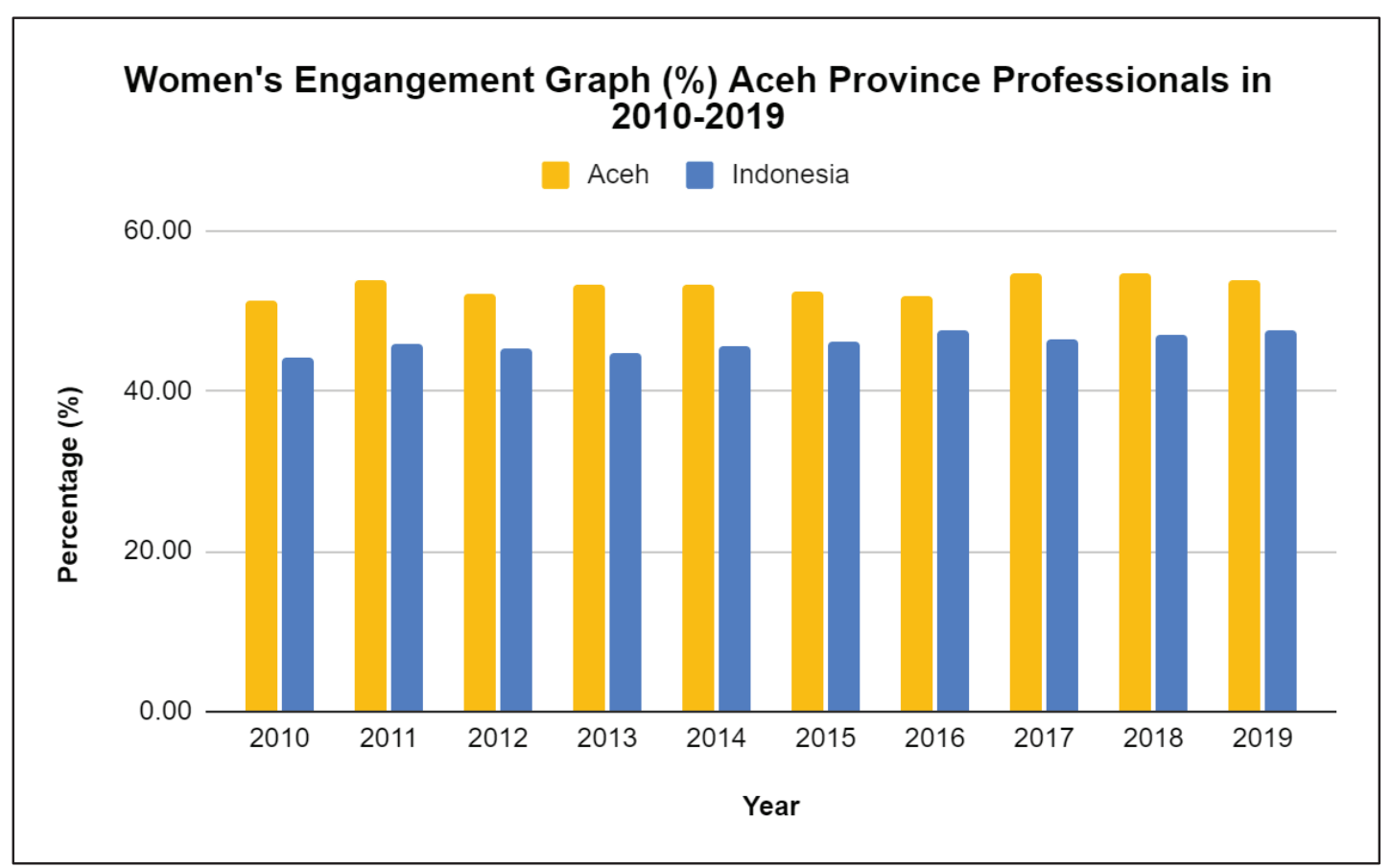

Fig. 7. Women as Professionals (\%) in Aceh Province 2010-2019

Source: BPS, processed (2021) 
When viewed at the provincial level, based on Figure 7. the percentage of female involvement as professed personnel experienced a patterned fluctuating trend. The percentage increase in the percentage of women's involvement as professionals continued to occur in 2010-2011, 2013-2014, and 2016-2017. During 20102011 the percentage of women's involvement as professionals increased by $2.53 \%$ from $51.14 \%$ in 2010 to $53.67 \%$. In $2013-2014$, the percentage of women's involvement as professionals in Aceh Province increased by $0.14 \%$ from $53.14 \%$ in 2013 , in 2014 to $53.28 \%$. Meanwhile, in 2016-2017 the percentage of women's involvement as professionals increased by $3.01 \%$ from $51.7 \%$ in 2016 , in 2017 to $54.71 \%$.

The increasing percentage of women as professionals indicates that women's crucifixion in making decisions and participating in the economy is increasingly aligned with men. This is in accordance with article 14 paragraph 1 in Qanun Aceh No. 6 of 2009 which states that the Government of Aceh and the Government of district/city and other institutions must provide the widest possible opportunity for women to occupy various positions at all levels of work professionally and proportionally.

The decrease in the percentage of female involvement as a professional force occurred in 2011-
2012, 2014-2016, and 2017-2019. The percentage of involvement of women as professionals in 2011-2012 decreased by $1.64 \%$. The percentage decrease in the percentage of female involvement as professionals in 2014-2016 was $1.58 \%$. Meanwhile, the percentage of women's involvement as professionals in 2017-2019 decreased by $0.79 \%$.

The percentage graph of women's involvement in professionals by district/city in Aceh Province from 2010-2019 is used to determine its distribution and distribution in each region (figure 8). The percentage of female involvement in professionals in Bireun District in 2010-2019 was the highest in Aceh Province. Even the percentage has reached $63.99 \%$. While the district that has the lowest percentage of female involvement in professionals is in Simeulue District, which is $37.78 \%$. There is a high gap between districts/cities in Aceh Province. This is influenced by several factors including the type of employment, the participation rate of the labour force, and the last level of education that is completed in the area. The increasing percentage of the female workforce should be accompanied by an increase in gender-biased employment to absorb the labour force without gender discrimination.

\section{Womens Engagement Graph (\%) Aceh Province Professionals by District or City in 2010-2019}

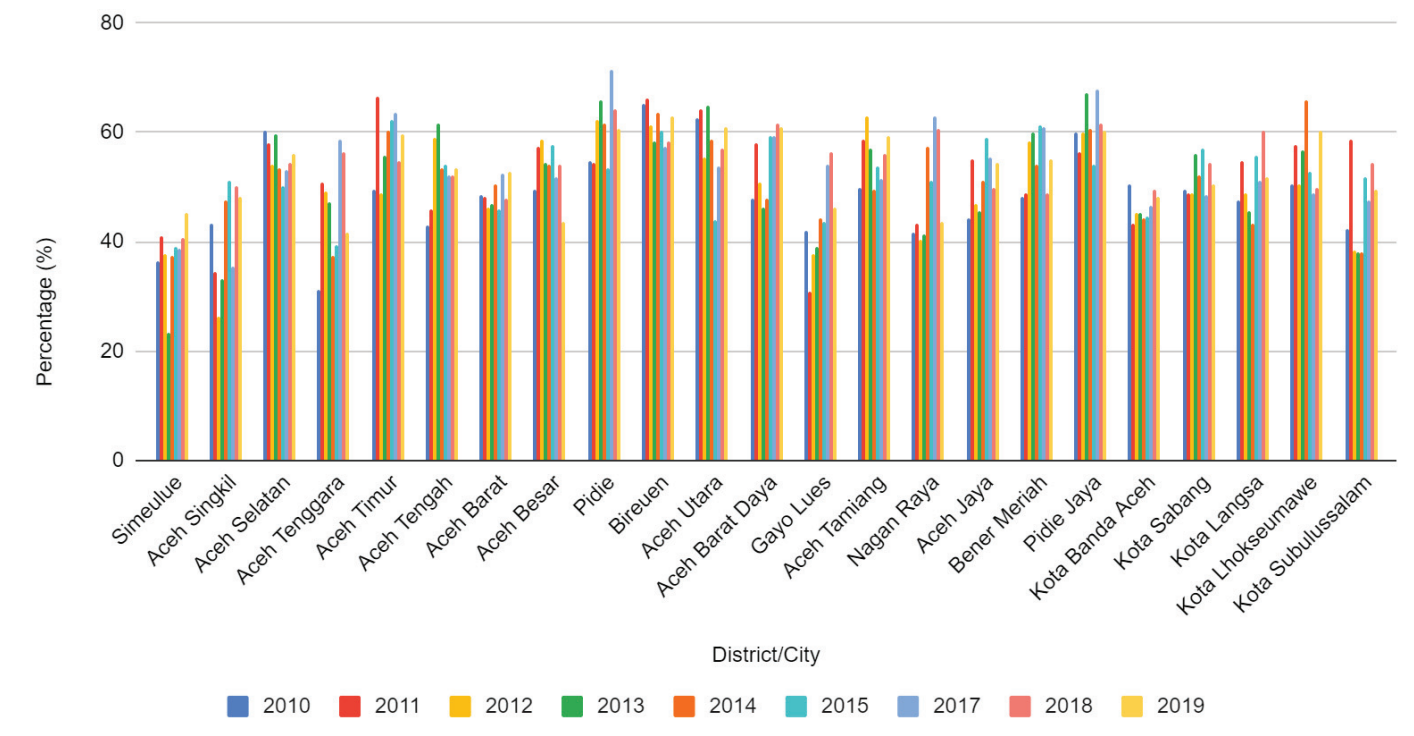

Fig. 8. Women as Professionals (\%) in Aceh Province by District or City 2010-2019

Source: BPS, processed (2021) 


\section{Conclusions}

The results of the analysis showed that the implementation of Qanun Aceh Number 6 of 2009 related to gender empowerment in Aceh Province has not been carried out to the maximum in 2010-2019. This can be seen from the condition of the gender empowerment index in Aceh Province which experienced a volatile trend from 2010-2019 with an index ranging from 52.06 to 67.4 which is still below the national figures. The three components of the gender empowerment index show quite different results. The component of women's involvement in parliament in Aceh Province still does not meet the minimum percentage of $30 \%$ and there is a percentage gap for some district and municipal administrative areas. The component of women's income contribution tends to increase the percentage figure throughout 2010-2019 which is not so significant and has met a minimum percentage of $30 \%$, but the value is still below the national figure. The component of women's involvement as professionals has a volatile trend and has met a minimum percentage of $30 \%$ with a value above the national figure.

\section{References}

1. M. K. Singh, Womens. Stud. Int. Forum, 71 (2018)

2. D. Richardson, Conseptualising Gender, in Introducing Gender and Women's Studies, no. June, Basingstoke, Palgrave Macmillan (2015)

3. World Economic Forum, Global gender gap report 2013: Ethiopia, Geneva [Website] (2013) (papers2://publication/uuid/BA7EA38E-351D450B-A186-7B7C581087DF, accessed 9 June 2021)

4. Pemerintah Provinsi Aceh, Qanun Aceh Nomer 6 Tahun 2009 tentang Perlindungan dan Pemberdayaan Perempuan (2009)

5. I. M. Dini, Fajriyah, Y. Mahdiah, E. Fahmadia, I. Lukitasari, Pembangunan Manusia Berbasis Gender 2020 (2020)
6. BPS, Indeks Pemberdayaan Gender (IDG) 2010$2020 \quad$ [Website], (2020) (https://www.bps.go.id/indicator/40/468/6/indekspemberdayaan-gender-idg-.html, accessed 9 June 2021)

7. Astusti, D. Dileli, Kalimantan Tengah Predikat Indeks Pemberdayaan Gender Tertinggi di Indonesia [Website], (2021) (https://dp3appkb.kalteng.go.id/artikel/kalimantantengah-predikat-indeks-pemberdayaan-gendertertinggi-di-indonesia.html, accessed 9 June 2021)

8. Pemerintah Republik Indonesia, Undang Undang Nomor 11 Tahun 2006 Tentang Pemerintahan Aceh (2006)

9. J. Biegon, Gender Equality and Political Processes in Kenya: Challenges and Prospects (Strathmore University Press, 2016)

10. O. Ojigo, The Impact of Article 9 of the Protocol to the African Charter on Human and Peoples' Rights on the Rights of Women in Africa on women's political participation in Africa. In Gender Equality and Political Processes in Kenya: Challenges and Prospects. Strathmore University Press (2016)

11. D. A. Putrie, A. Rahman, Analisis dan Pemodelan Pendapatan Pekerja Perempuan di Indonesia Menggunakan Data Panel, in Seminar Nasional Official Statistics 2019: Pengembangan Official Statiistics dalam Mendukung Implementasi SDG's (2018)

12. H. Mudzhar, Anto, Wanita dalam Masyarakat Indonesia: Akses, Pemberdayaan, dan Kesempatan (Sunan Kalijaga Press, Yogyakarta, 2001)

13. E. Andina, Pencapaian Millenium Development Goals Bidang Pemberdayaan Perempuan dan Perlindungan Anak (Penerbit Pusat Pengkajian Pengolahan Data dan Informasi, Jakarta, 2012)

14. J. Schieder, E. Gould, Women's Work' and the Gender Pay Gap, Washington DC, 2016. [Online]. Available: epi.org/110304.

15. C. F. Oktari, Sartiyah, J. Ilm. Mhs., 5, 2, (2020).

16. R. Zahara, Karakteristik Pengangguran Perempuan Berdasarkan Pendidikan di Kota Banda Aceh (Banda Aceh, 2018)

17. W. Rajagukguk, J. Ketenagakerjaan, 10, 1, (2015) 